\title{
39. CORRELATION OF CORE AND SEISMIC STRATIGRAPHY BY MEANS OF VERTICAL SEISMIC PROFILING, AND DOWNHOLE AND PHYSICAL PROPERTIES MEASUREMENTS FOR THE LEG 126 FOREARC SITES $(787,792 \text {, AND 793 })^{1}$
}

\author{
P. A. Cooper, ${ }^{2}$ K. A. Dadey,${ }^{3}$ A. Klaus, $, 2,4$ M. A. Lovell, ${ }^{5}$ P. A. Pezard, ${ }^{6}$ and B. Taylor ${ }^{2}$
}

\begin{abstract}
Correlation of the logs from the Izu-Bonin forearc sedimentary sections at Sites 787, 792, and 793 with the core data from Holes 787A-787B, 792A-792E, and 793A-793B allows the development of a more detailed lithostratigraphic model for those sites, and a more precise correlation of lithologic boundaries to basin-wide seismic reflections. Early Oligocene arc volcanics form the basement strata (Unit 5) sampled at Sites 792 and 793. Downdropped and rotated blocks of Eocene forearc may form a sub-basement beneath these flows in the central forearc basin; mid-Eocene basement was recovered at Sites 782 and 786 on the outer-arc high during Leg 125. Basement at Site 792 was defined using the vertical seismic profile (VSP) and logging data. Deep reflectors observed on the vertical seismic profile may originate in the Eocene sub-basement. Thick sequences of coarse-grained volcaniclastic and hemipelagic sediment fill the 70- to $140-\mathrm{km}$-wide forearc sedimentary basin. Unrecovered (early Oligocene) strata beneath an unconformity, imaged by the multichannel seismic (MCS) line passing over Site 792, fill the deepest grabens of the central forearc and constitute Unit 4. The rapid deposition of volcaniclastics (Unit 3) during a dominant eruptive phase spanning much of the Oligocene, together with erosion of the basement highs bounding the basin, contributed to rapid subsidence and infilling. An inspection of cored materials from Unit 3 and logging data from Sites 792 and 793 reveals microfaults and other structural evidence for extension; on a much larger scale, MCS data show large normal faults near the frontal-arc high and outer-arc high that downfault the sediment section towards the central basin. Much of the largely pelagic or hemipelagic early Miocene section (Unit 2) has been removed by submarine valley formation and erosion, as at Sites 787 and 792. Middle Miocene to Holocene volcaniclastics and hemipelagics (Unit 1) top the forearc sedimentary section.
\end{abstract}

\section{INTRODUCTION}

We derive a regional seismic stratigraphy for the Izu-Bonin forearc by correlating drillhole data to a network of multichannel seismic (MCS) lines. Three sites within the Izu-Bonin forearc were drilled during Leg 126 (Fig. 1). Site 787 was drilled at the eastern edge of the Izu-Bonin forearc sedimentary basin, within the axis of Aoga Shima Canyon. Site 792 was located in the western Izu-Bonin forearc sedimentary basin, upslope from a fork in Aoga Shima Canyon, where the strata lap onto the edge of a basement high. Site 793 was situated in the center of the Izu-Bonin forearc sedimentary basin, in an interchannel area on the southern side of the broad Sumisu Jima Valley. Only Sites 792 and 793 were logged. Detailed descriptions of the Schlumberger logging tools and their use in scientific drilling may be found in Herzog et al. (1987), Anderson et al. (1990), and Lovell and Anderson (1988).

Correlations of site survey multichannel seismic data (Fred Moore cruise numbers 3505 and 3507) with recovered core material and to downhole geochemical data was accomplished for all sites by using physical properties velocities, averaged over each lithologic unit, or subunit, to convert the two-way traveltimes to depths. Vertical seismic profile (VSP) data obtained at Site 792 clarify the depth location of reflectors as determined from physical properties velocities and define basement. The correlation of reflector depths to changes in

'Taylor, B., Fujioka, K., et al., 1992. Proc. ODP, Sci. Results, 126: College Station, TX (Ocean Drilling Program).

${ }^{2}$ Department of Geology and Geophysics, University of Hawaii, 2525 Correa Road, Honolulu, HI 96822, U.S.A.

${ }^{3}$ Graduate School of Oceanography, University of Rhode Island, Narragansett, RI 02882, U.S.A.

${ }^{4}$ Present address: Ocean Research Institute, University of Tokyo, 1-15-1 Minamidai, Nakano, Tokyo 164, Japan.

${ }^{5}$ Borehole Research, Department of Geology, University of Leicester, University Road, Leicester LEI 7RH, United Kingdom.

${ }^{6}$ Institut Méditerranéen de Technologie, Départment de Génie Océanique, Technopôle de Château-Gombert, 13451 Marseille Cedex 13, France. lithology and other physical properties, where available, such as density, porosity and water content, and geochemical logging data is quite good. This suggests that the interval velocities used to calculate the depths are approximately correct.

The five major seismostratigraphic units represent developmental stages of the forearc: (1) 0-17 Ma, middle Miocene to Holocene explosive volcanism; (2) 17-27 Ma, early Miocene hemipelagic carbonates and clay deposited during a period of volcanic quiescence following waning late Oligocene volcanism; (3) 27-30 Ma, extensive late Oligocene explosive volcanism and erosion of highs surrounding the forearc basin; (4) early Oligocene graben fill; and (5) late Eocene basement (P. A. Cooper et al., unpubl. data, 1992). Throughout this report, lithologic units are identified by Roman numerals; the five seismic units are identified by Arabic numerals. Seismic Unit 1, middle Miocene to Holocene volcaniclastic sequences, consists of numerous parallel, locally divergent, high-amplitude reflectors. Many depositional unconformities are present within drilled sections of this sequence. Some of them represent pinch-outs over the frontal-arc high; more complete sections are present to the west of the forearc high, proximal to the arc. Within the forearc basin, Unit 1 shows evidence of canyon cut-and-fill and other bottom-current-induced erosional and depositional features. Seismic Unit 2, the early Miocene hemipelagic sequence, is characterized by parallel, continuous, undulating, very low-amplitude reflectors. Seismic Unit 3, consisting of upper Oligocene volcaniclastic turbidite sequences, is the most regionally extensive sequence in the forearc and is extensively faulted throughout the forearc basin. It is characterized by parallel, discontinuous, high-amplitude reflectors. Seismic Unit 4, the early Oligocene graben-fill sequences, also extensively faulted, is characterized by subparallel-to-chaotic, mediumamplitude reflectors that are often sharply angular to the overlying unit. Individual reflectors at the base of this unit are typically conformable to basement topography. Seismic Unit 5, acoustic basement, is poorly defined in parts of the basin because of its highly stratified nature and because of its low velocity contrast to the basal sediment. Where the upper part of the igneous basement is highly altered (as determined by drilling), basement is defined by a continuous, high-amplitude reflector. Coherent 


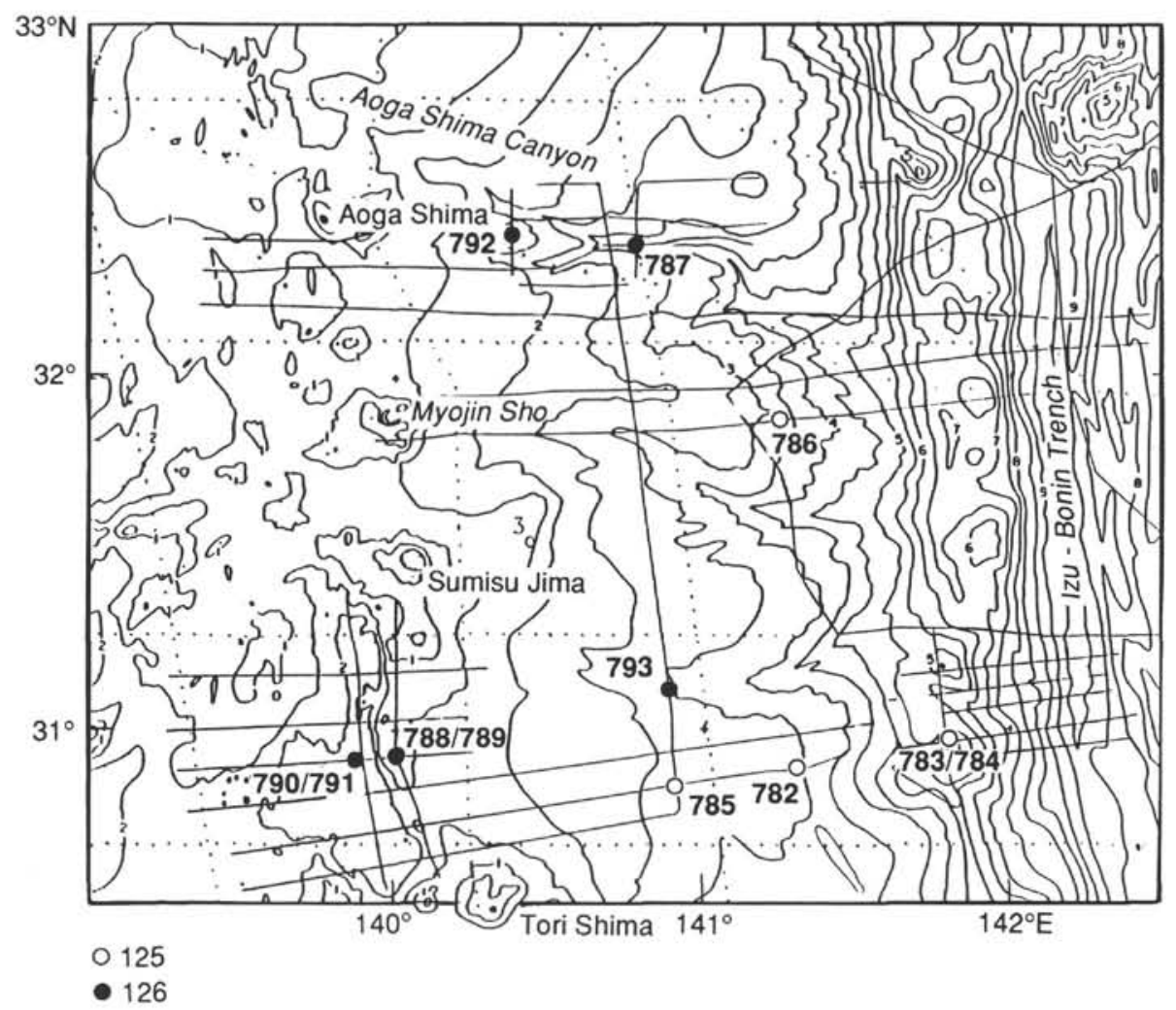

Figure 1. Location map showing multichannel lines and drill sites on Legs 125 (open circles) and 126 (filled circles). Contour interval $=500 \mathrm{~m}$ (numbers on contour lines indicate depth in $\mathrm{km}$ ).

reflectors are identified down to $4.5 \mathrm{~s}$ below seafloor (sbsf) on some record sections.

\section{SITE 787}

Site 787 lies on multichannel seismic (MCS) Line 2 (Fred Moore 3505) at 0710 Zulu (Z) (Fig. 2). The site is located in the axis of Aoga Shima Canyon where erosion has removed an estimated $1 \mathrm{~km}$ of section. Lithologic Units I and II together form a veneer of unconsolidated materials that lie unconformably atop the lithified, eroded Oligocene section. The lower Pleistocene unsorted, pumiceous, and scoriaceous sandy gravels of Unit I were probably redeposited from upslope. Directly beneath the Pleistocene gravels is a very thin Unit II, consisting of Pliocene and upper Miocene oozes and clays, some of which may have been redeposited. Unit II is unconsolidated, representing intermittent hemipelagic deposition during periods of canyon erosion. An interpretive sketch of the MCS record section (Fig. 3) was made by correlating the lithologic boundaries assigned from a study of the drill cores to prominent reflectors. The unconformity-bound Units I and II cannot be characterized seismically because they occur within the seismic bubble pulse. The middle and lower Miocene have been removed by canyon erosion. The high-amplitude, sub-bottom reflector at $4.45 \mathrm{~s}$ (Fig. 3) probably defines the base of Unit II.

Drilling at Site 787 ended prematurely because of hole collapse at a total depth of $320.1 \mathrm{mbsf}$; it sampled only the topmost strata of the Oligocene seismic section (Unit 3). No logging or VSP was performed at Site 787. Based on evidence from Sites 792 and 793, the low-amplitude, parallel, downlapping reflectors of Unit 3 are consistent with alternating thicknesses of fine-grained interbedded hemipelagics and volcaniclastics and coarse-grained volcaniclastics. Note that the automatic gain control (500-ms window) has lowered their amplitude relative to the rest of the section; this is a result of the high-amplitude signals associated with the seafloor and the coarse sands and gravels of Subunit IVB.

The seismic section, from bubble pulse to about $5.36 \mathrm{~s}$, consists of parallel, continuous, medium- to high-amplitude reflectors. Within this interval, two very high-amplitude reflectors at $4.67 \mathrm{~s}$ (Fig. 3, Reflector "a") and $4.52 \mathrm{~s}$ define the top and base of Subunit IVA, corresponding to sharp changes in velocity, density, and grain size. These reflectors lap onto a westward-dipping, high-amplitude sequence (5.36-5.77 s) that, in turn, laps onto the acoustic basement. Reflectors R3 and R4, representing an early Oligocene unconformity and basement, respectively, were not sampled by the drill. The large basement high introduces uncertainties in the correlation of Reflector R3 elsewhere in the basin. Unit III consists of upper Oligocene, predominantly hemipelagic sediment, deposited in a distal, deepwater setting. The unit is consolidated, indicating previous significant overburden. All upper Oligocene strata are extensively burrowed; extensional microfaults evidence extensional deformation. Subunit IVA consists of upper Oligocene graded sandstones interbedded with carbonates, hemipelagics, and graded sandstones and claystones. The turbidite units show slight mottling and indistinct layering; the alteration in the layers suggests that the carbonate layers represent repeated influxes of sediment, whereas at other times such processes were nil. Perhaps the difference could be related to changes in tectonism or bottom currents in the source area; more likely, however, there were changes in the levee heights, locations, and pathways along the distributary channels fed from the Izu-Bonin Arc. The pelagic clays may represent background sedimentation or solution facies. Grain sizes and porosities for Units III and IV are similar. Chalk, lapilli tuff, and volcanic ash layers interbedded with the fine-grained materials probably produce the low-amplitude, discontinuous reflectors that characterize this part of the seismic section. Sonic velocities increase slightly from an average of $1.8 \mathrm{~km} / \mathrm{s}$ in Unit III to $2.2 \mathrm{~km} / \mathrm{s}$ in Unit 
W Site

787

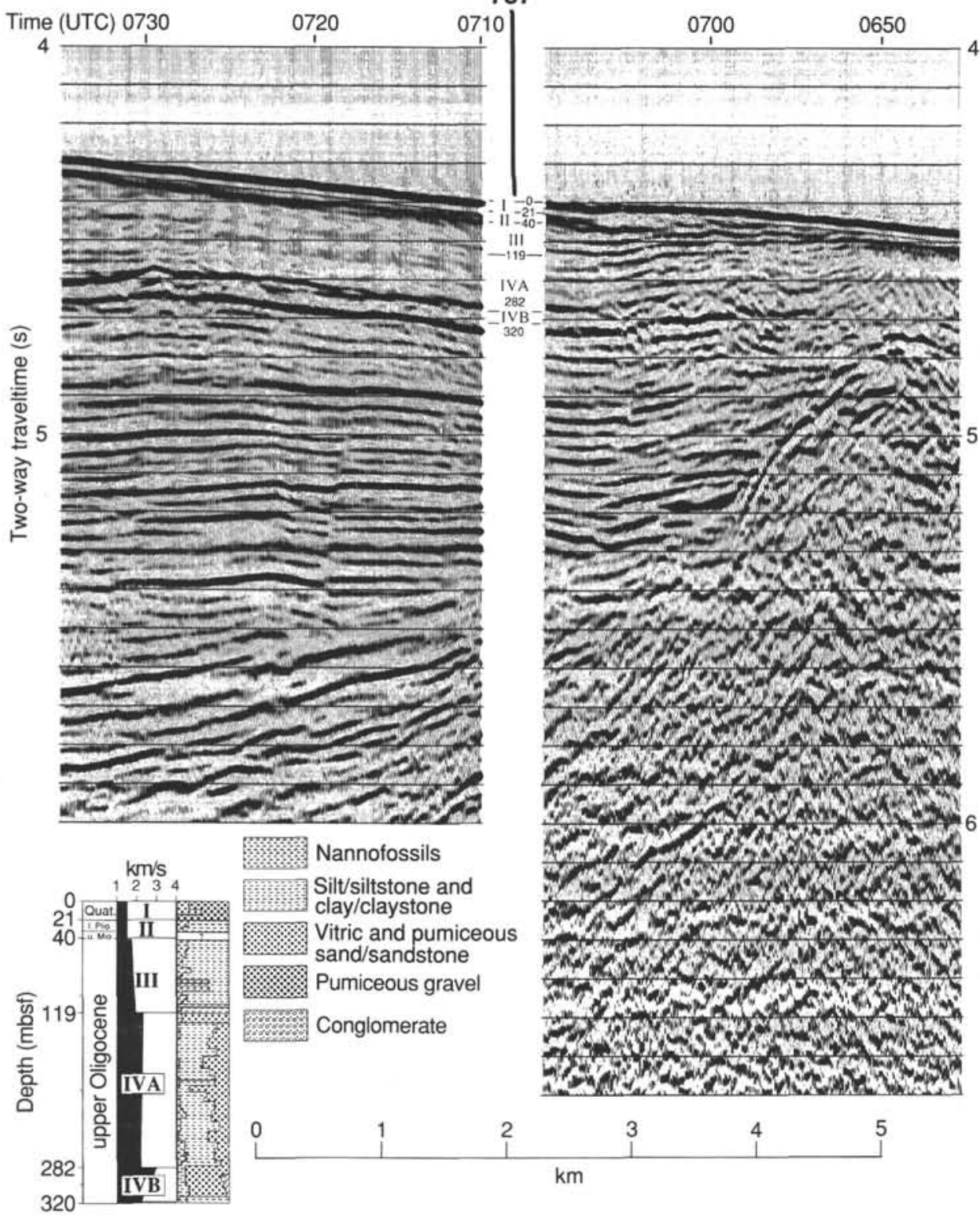

Figure 2. Correlation of Site 787 lithostratigraphy with site survey multichannel reflection data. Lithologic units are identified on the same section, unit boundaries are given in meters below seafloor (mbsf), and the lithologic column is presented in the lower left corner. The location of the seismic line is shown in Figure 1. The seismic section has been stacked (48-fold), deconvolved, migrated, and filtered 10-60 Hz. Vertical exaggeration is about $4 \times$.

IV. Calcium carbonate and bulk density values decrease at this boundary. Because carbonate dissolution is minimal at this site, the lower $\mathrm{CaCO}_{3}$ content in Unit IV probably results from a relative increase in volcaniclastic content (Taylor, Fujioka, et al., 1990).

\section{SITE 792}

Site 792 was located in the western portion of the Izu-Bonin forearc basin, along Fred Moore 3505 seismic Line 10 at 0134 Z (Fig. 4). The section dips away from the basement high, with dips decreasing upward in the section. A complex system of growth faults cuts the Oligocene sequence (Unit 3; Fig. 5). Some large faults have expression into basement. The seismic character is consistent with the character of the physical properties measurements and the logs. Lithologic Units I and II were not logged. The velocity analysis developed for Site 792 from the MCS data was used for initial depth determinations; before drilling, the depth to acoustic basement was estimated to be $850 \mathrm{mbsf}$. Coring established the boundary between the altered zone (Unit V) and the basement (Unit VI) to be at $804 \mathrm{mbsf}$; the difference is not surprising considering the large volume of low-velocity material at shallow depths. The velocity changes across these boundaries were logged and are discussed below. A VSP was run at this site to relate reflectors as seen on MCS profiles to variations in lithologic and physical properties as determined from core materials and to obtain as complete a characterization of the thick stratigraphic section as possible. 


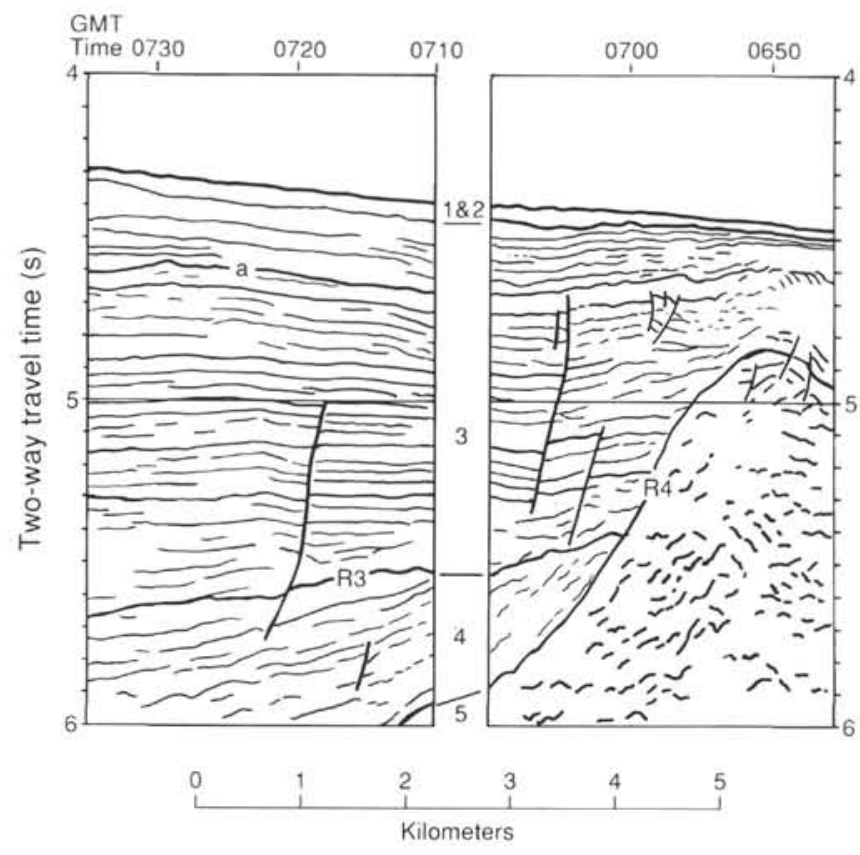

Figure 3. Interpretation of MCS Line 2 near Site 787 showing major Reflectors "a," R3, and R4 and Seismic Units 1 through 5. See text for further explanation.

\section{Zero-offset Vertical Seismic Profile}

A summary and history of borehole seismic experiments conducted as part of the scientific ocean drilling program is included in Mutter and Balch (1988). Before Leg 126 several experiments had been conducted, including an offset experiment during Leg 102. Conventional zero-offset VSPs had been conducted in ocean crust during Legs 104, 111, and 118 and in a thick sediment section during Leg 123. Logging Run 5 at Hole 792E produced excellent vertical seismic profile (VSP) data. They are used here to tie the surface multichannel seismics to the well logs and physical properties data to help (1) refine the MCS-core correlations; (2) identify the synrift sedimentary rocks and prerift sedimentary rocks, and (3) determine the seismic character of the basement.

The sound source used was the large volume (400 in. ${ }^{3}$, or 161), high-pressure ( $2000 \mathrm{psi}$, or $140 \mathrm{bar}$ ) SSI-H400 water gun aboard the JOIDES Resolution. The gun was suspended $15 \mathrm{~m}$ below sea level (mbsl) from a buoy tethered from the drillship's aft port crane boom, about $24 \mathrm{~m}$ abeam. The downhole seismic signals were received by a Schlumberger well seismic tool (WST), single-vertical-component seismometer. The seismometer has four, series-connected, $10-\mathrm{Hz}\left(\mathrm{F}_{0}\right)$ geophones mounted at its base. The water-gun acoustic signals also were detected by a separate, calibrated hydrophone suspended from the crane boom, $3 \mathrm{~m}$ below the water gun. This hydrophone configuration provided a stable, zero-time reference relative to the seafloor, allowing real-time visual inspection, selection, and summing of the several shots fired at each seismometer clamping level.

The WST was lowered to the bottom of the hole (Level 1, 868.66 mbsf) and clamped to the side wall. The cable was then slacked $2 \mathrm{~m}$, and a single shot was fired to test for noise or poor coupling to the borehole wall. The seismogram waveforms recorded for each shot were displayed in nearly real time on a TEKTRONIX graphics terminal. After ascertaining that the seismometer was properly clamped to the well bore, additional shots were taken as deemed necessary by the operators and stacked for real-time display. The normalized stacked trace was then displayed and inspected before moving on to the next clamping level. A satisfactory signal-to-noise ratio was obtained using five shots per level. Following the shooting/inspection/stacking sequence, the WST was raised $9.14 \mathrm{~m} \mathrm{(30} \mathrm{ft)}$; the sequence was repeated at 9.14-m intervals to the last clamping level at 292.63 mbsf. Data obtained within the drill pipe ( $\$ 87 \mathrm{mbsf}$ ) were extremely noisy, and attempts to properly clamp the instrument to the drill pipe were too time consuming to warrant continuation of the VSP to the seafloor.

Water-gun-generated signals received by the WST borehole seismometer were preamplified downhole, transmitted by means of the logging cable, and digitally recorded along with the hydrophone signals by the PDP-11 minicomputer and A/D converter of the Schlumberger CSU logging data acquisition system. Timing information was accurate to within $0.01 \mathrm{~ms}$. The data sampling rate was $1 \mathrm{~ms}$ with a record length of $3 \mathrm{~s}$.

Land-based seismic processing of the VSP data was accomplished at HIG using VISTA Seismic Software. Standard techniques for processing VSP data include the application of static corrections, calculation of velocity-depth profiles, and wave-field separation (Gal'perin, 1974; Hardage, 1983; Balch and Lee, 1984).

The signal-to-noise ratio was high throughout the experiment. Borehole diameter was fairly uniform except in the region of clamping levels 47, 48, and 49 (411.49-429.78 mbsf). High-frequency tool resonance, seen in the upper-level traces, increased as the tool neared the bottom of the drill pipe at 287.0 mbsf. The data in Figure 5 are filtered $10-60 \mathrm{~Hz}$; a spreading-loss-type, 1.5 -power exponential time gain factor was applied to display the weaker, deeper signals. Each trace-amplitude scale is normalized. The downgoing direct waves are the strong first arrivals with traveltime increasing with depth. Note that no water-bottom multiples are seen on the section because the one-way traveltime through the water column is $1200 \mathrm{~ms}$. The threeway traveltime $(3600 \mathrm{~ms})$ for a VSP-type, water-bottom multiple is well beyond the record length displayed. The upgoing reflected waves are the late, weak (but coherent) events, with traveltime increasing as depth decreases. The divergence of the downgoing and upgoing wave trains results from the decreasing range to the sound source for the direct waves, and the increasing range from the reflecting surface as the WST is raised.

Reflectors seen in Figure 6 and subsequent figures are identified by letter names; many of these reflectors have been related to lithology and associated changes in acoustic impedance. Numerous internal reflections also can be seen in Figure 6. A high-velocity zone ( 2.77 $\mathrm{m} / \mathrm{s})$ in the uppermost part of Unit IV (429-450 mbsf) generates a set of internal reflections seen originating near the 457.21 -mbsf recording level. A strong reflector, SB, originates at approximately 1259 mbsf, beyond the total depth drilled. The reflected wave trains intersect the direct wave's first break arrival at the depth of the interface causing the reflection; in practice, if the direct wave has a complex waveform, it is difficult to define that intersection.

Traces were time-shifted by an amount equal to the direct-wave first-break traveltime. A spatial velocity filter was then applied to the resulting partial two-way traveltime section to separate the upward propagating reflected wave trains from the downward-propagating wave trains. The data were not corrected for the minor deviations of the borehole from the vertical. Figure 7 is a display of the filtered, wave-shape-deconvolved, upgoing wave trains. Prominent reflectors have been identified and related to lithologic units or subunits. Reflectors defining major unit boundaries (Units III through VI; Units I and II were not logged) are identified on this figure and are correlated directly to multichannel seismic data in Figure 8 . The correlation of the major reflectors on the VSP and MCS data is good, but certainly not on a one-to-one basis. This is because differences in acquisition (frequency content) and processing parameters (gain levels, filter bandwidths) produce the differences in appearance of the various seismic data. Correlations between the deeper reflectors ( $E$ through A) on the MCS and VSP data are not attempted, since the reflectors below Reflector $\mathrm{G}$ indicate dipping strata. Table 1 summarizes all VSP correlations. Figure 9 illustrates the excellent correlation between 


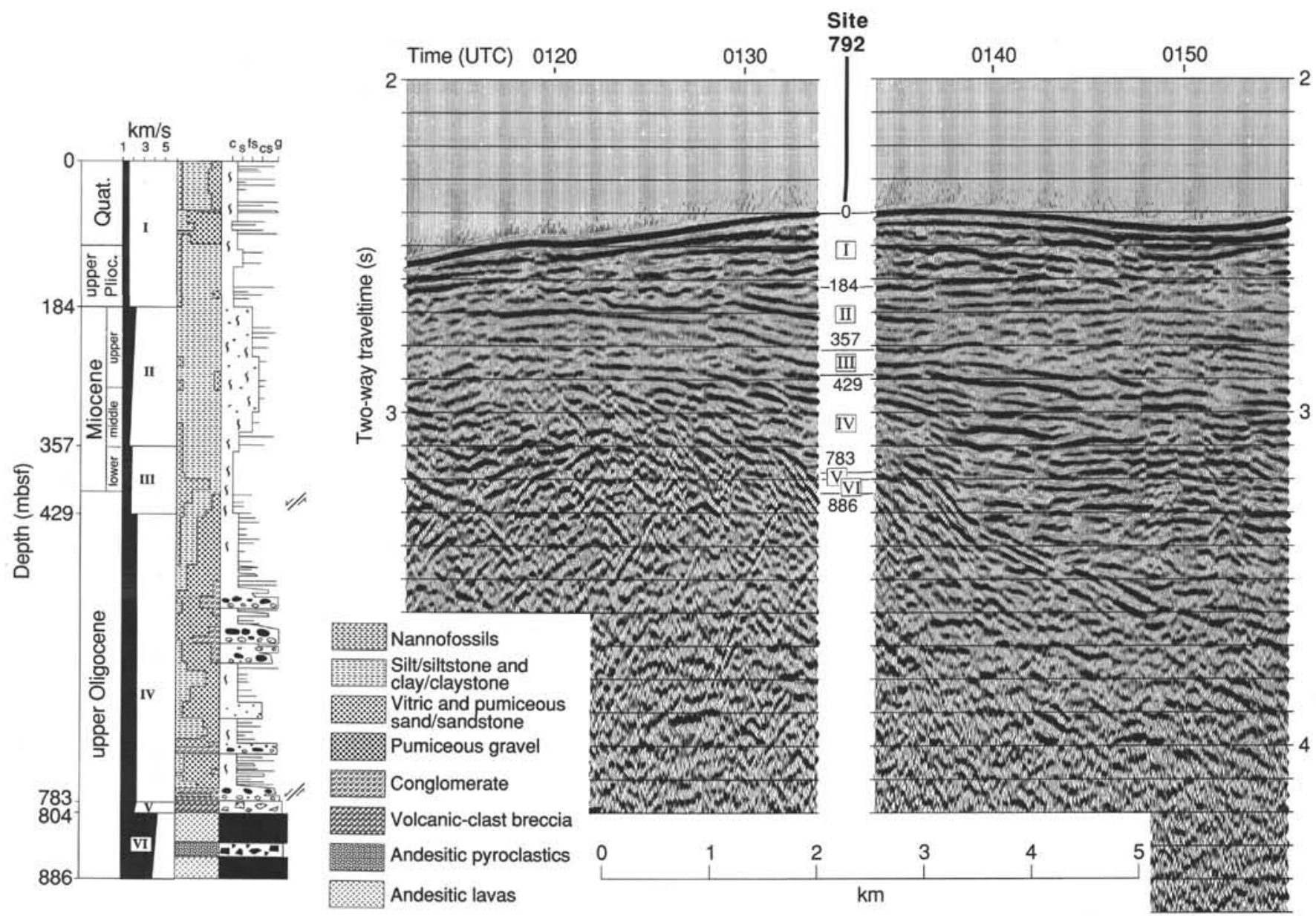

Figure 4. Correlation of Site 792 lithostratigraphy with site survey multichannel reflection data. Lithologic units are identified on the same section, unit boundaries are given in meters below seafloor (mbsl), and the lithologic column is presented in the lower left corner. The location of the seismic line is shown in Figure 1. The seismic section has been stacked ( 48 -fold), deconvolved, migrated, and filtered 10-60 Hz. Vertical exaggeration is about $4 \times$.

VSP interval velocity data averaged over the designated lithostratigraphic intervals, with velocity data obtained by physical properties measurements and downhole measurements.

The VSP data were essential to defining the location of basement on the regional MCS data. Basement in the region is difficult to define because of the numerous dipping reflectors that pinch out against apparent basement highs. Reflector G (777.23-786.37 mbsf) consists of a strong positive paired with a very strong negative. This reflector originates within a depth range that contains the Unit $\mathrm{V}$ basal conglomerates, underlain by a low-velocity altered zone. The Reflector F (792.52-804.67 mbsf) is the top of volcanic basement. Before drilling, another MCS reflector, possibly corresponding to Reflector $\mathrm{B}$, was identified as basement. It is now obvious that Reflector B is a sub-basement reflector, as are Reflectors C, D, and E. Their origin is directly related to the alternating massive (high-velocity) and brecciated (low-velocity) subunits that constitute basement throughout most of the forearc region.

A synthetic VSP was calculated from the laboratory velocity and density measurements using the full-waveform reflectivity method of Mallick and Frazer (1988), but it was not very insightful (Fig. 10). The synthetic downgoing arrivals differ slightly from the data because velocities measured in the lab are slightly lower than the VSP velocities for the uppermost sediment column and higher than VSP velocities in the basement. Only basement can be clearly identified on the synthetic VSP. Question marks accompany the rather tenuous identification of Reflectors $\mathrm{P}$ and $\mathrm{H}$.

\section{Physical Properties Measurements and Geochemical Logging}

An interpretive sketch of the MCS record section (Fig. 5) near the drill site was made by correlating the lithologic boundaries assigned from a study of the drill cores to prominent reflectors using physical properties velocities. The unit boundaries were also correlated to the Hole $792 \mathrm{E}$ velocity log at major changes in velocity nearest a unit boundary. The deepest coherent reflector has a very low-frequency response, and its highly diffractive character indicates point reflective sources, probably from small basement faults. The prominent Reflector $\mathrm{R} 3$ represents an unconformity just below the oldest section drilled $(29 \mathrm{Ma})$ at Site 792 . Unit 3 has the strongest sequence of coherent reflectors; these are occasionally broken by small faults, particularly in the middle part of the sequence. Unit 2 is characterized by low-amplitude, continuous reflections. Unit 1 is characterized by high-amplitude, broken, locally divergent, often pod-shaped reflectors, strong evidence for canyon formation and migration.

Seismic Unit 1 (2.4-2.84 s) consists of numerous subparallel, locally divergent (lenticular near Site 792), high-amplitude reflectors; it corresponds to lithologic Unit I and the upper portion of Unit II. The lenticular reflector package (Fig. 4) may be interpreted as either channel deposits or as a bottom-current-induced depositional feature. The Unit I/II boundary is marked by a hiatus: unconsolidated upper Pliocene strata lie unconformably atop consolidated upper Miocene strata. The hiatus separating Units I and II is not well defined in the 


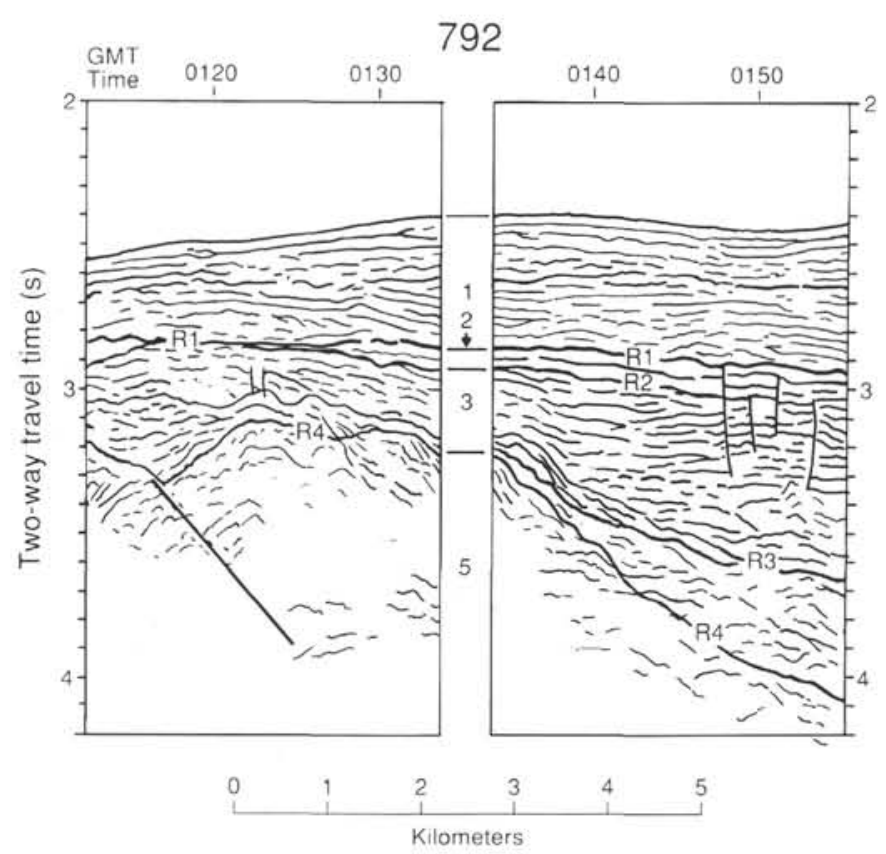

Figure 5. Interpretation of MCS Line 10 near Site 792 showing major Reflectors R1, R2, R3, and R4 and Seismic Units 1 through 5. A large basement fault is shown in the lower left. See text for further explanation.

logs, probably because of extensive mixing caused by burrowing in the topmost $10-15 \mathrm{~m}$ of Unit II. Nevertheless, a sharp drop in aluminum and an increase in iron and hydrogen occurs at the boundary (Fig. 11; Taylor, Fujioka, et al., 1990). Across the boundary there is a slight increase in density, from 1.99 to $2.10 \mathrm{~g} / \mathrm{cm}^{3}$ and an increase in velocity from 1.59 to $1.85 \mathrm{~km} / \mathrm{s}$. The sedimentation rate in Unit I is $120 \mathrm{~m} / \mathrm{m}$.y., decreasing to $23-43 \mathrm{~m} / \mathrm{m}$.y. at the top of Unit II. Within Unit II, a sharply defined hiatus separates the middle and late Miocene; this hiatus is evident on almost all logs and is marked by the reflector at $2.72 \mathrm{~s}$ (Fig. 4): salinity, porosity, aluminum (wet wt\%), and chlorine yields (decimal fraction) increase, whereas iron, silicon (decimal fraction), and hydrogen yields (decimal fraction) decrease.

Seismic Unit 2 (2.84-2.90 s) consists of parallel, continuous, undulating, low-amplitude reflectors; it corresponds to the lower portion of lithologic Units II and III. Although the Unit II/III boundary is marked by a minor hiatus (about $5 \mathrm{~m} . \mathrm{y}$.), there is only a slight increase in velocity from 1.85 to $1.87 \mathrm{~km} / \mathrm{s}$ and a decrease in density from $1.9 \mathrm{~g} / \mathrm{cm}^{3}$ in Unit II to $1.85 \mathrm{~g} / \mathrm{cm}^{3}$ in Unit III. Unit II is characterized by nearly constant resistivity (about $9 \Omega \mathrm{m}$ ), whereas resistivity is more variable in Unit III. A change in dip observed in the formation microscanner (FMS) logs for this depth level may be an indication of slumping. The smectite content increases either above this boundary or within Unit III, the exact depth cannot be resolved because of the sampling interval. At about $386 \mathrm{mbsf}$, within Unit III, the calcium concentration increases sharply in core material and downhole geochemical measurements. This event is marked by a weak reflector at $2.83 \mathrm{~s}$ on the MCS and VSP (Fig. 8, Reflector T).

The sedimentation rate decreases from $14 \mathrm{~m} / \mathrm{m}$.y. at the top of Unit III to $9 \mathrm{~m} / \mathrm{m}$.y. at the bottom; that is not a significant decrease and could represent a local variation. From 400 to $430 \mathrm{mbsf}$, there is a permeable zone, sharply defined by the caliper log (Taylor, Fujioka, et al., 1990). Above the permeable zone, from about 377 to $395 \mathrm{mbsf}$, potassium and uranium sharply peak, indicating some migration of these elements. At 405 mbsf, a hiatus between the lower Miocene and upper Oligocene is characterized by a sharp peak in $\mathrm{CaCO}_{3}$. That is also clear on the logs: the lithology indicator ratio and the porosity, iron, and silicon yields increase sharply, and the aluminum fraction and the calcium and hydrogen yields decrease (Fig. 11).

Seismic Unit $3(2.90-3.15 \mathrm{~s})$ is characterized by northwardly divergent, high-amplitude reflectors, offset by normal faults; this seismic unit corresponds to turbiditic, lithologic Unit IV. The Unit III/IV boundary shows slight velocity and density increases to 2.3 $\mathrm{km} / \mathrm{s}$ and $1.87 \mathrm{~g} / \mathrm{cm}^{3}$, respectively. There is a sharp increase in the deep induction $\log$, medium induction $\log$, and microspherically focused log at this boundary (Taylor, Fujioka, et al., 1990); the graded sandstones and siltstones interbedded with mudstone of the upper portion of Subunit IVA are strongly bioturbated. Lithologic Unit IV is divided into four subunits based on grain size (Taylor, Fujioka, et al., 1990): Subunits IVA and IVC are fine grained, whereas Subunits IVB and IVD are conglomeritic. At the top of Subunit IVA, there is a high-velocity zone $(2.77 \mathrm{~km} / \mathrm{s})$ to about $450 \mathrm{mbsf}$. This high-velocity zone creates the strong Reflector R2 (Fig. 5; Reflector R on Fig. 8), defining the Unit III/IV boundary. The velocity then drops to $2.15 \mathrm{~km} / \mathrm{s}$ from 450 to $480 \mathrm{mbsf}$. The Subunit IVA/IVB boundary is marked by an order-of-magnitude increase in sedimentation rate, from 32 to $300 \mathrm{~m} / \mathrm{m}$.y. VSP Reflector O (2.97 s on the MCS data), originating between the 512.07-521.22-mbsf recording levels, probably corresponds to the Subunit IVA/IVB boundary. Subunit IVB conglomerates contain numerous andesite-dacite clasts. Velocities are highly variable, and resistivity logs indicate a series of fining-upward sequences from 545 to 580 mbsf (Cores 126-792E-43R through $-46 R$ ). Average velocity within Subunit IVB is $2.77 \mathrm{~km} / \mathrm{s}$ and density is $2.16 \mathrm{~g} / \mathrm{cm}^{3}$.

At the Subunit IVB/IVC boundary, there is a sharp $(-0.5 \mathrm{~km} / \mathrm{s})$ velocity decrease to $2.28 \mathrm{~km} / \mathrm{s}$. A steplike decrease in resistivity occurs at $587 \mathrm{mbsf}$ and an increase in smectite content and magnetic susceptibility is measured in the cores. VSP Reflector N defines this boundary. Subunit IVC is strongly bioturbated; Subunit IVD consists of thick sandstone and conglomerate beds. The Subunit IVC/IVD boundary is marked by an increase in velocity to $2.58 \mathrm{~km} / \mathrm{s}$. Thorium and potassium increase sharply across the boundary.

Seismic Unit 4 (3.15-3.22 s) laps off basement just east of Site 792. Reflectors in Unit 4 are broken and difficult to follow, probably owing to the high degree of faulting and slumping inferred from the core material. Subparallel to discontinuous, medium-amplitude reflectors characterize this unit farther east. The onlap of Unit 4 reflectors onto the altered zone above basement indicates that a major unconformity is present near the sediment/basement contact. The Unit IV/V contact is probably faulted, based on fracture evidence observed in the cores; the caliper log (Taylor, Fujioka, et al., 1990) reveals a series of short permeable intervals at the base of Subunit IVD and two distinctly larger permeable zones at the top and base of Unit V. A sharp velocity drop to $2.2 \mathrm{~km} / \mathrm{s}$ is accompanied by a drop in density to $2.02 \mathrm{~g} / \mathrm{cm}^{3}$ at the IV/V contact. Identification of this sequence boundary in cores and logs is complicated, in that the resolution of the seismic data is $\pm 1 / 4$ dominant wave length; the observed reflected arrival is a composite, resulting from impedance changes over a fairly broad interval. Unit V stands out in the logs and physical properties measurements drop at the Unit IV/V boundary and stay low throughout Unit V. Porosity is $50 \%$ based on lab measurements. Cores consist of highly altered material.

Seismic Unit 5 (acoustic basement; $>3.2$ s) consists of chaotic, discontinuous reflectors of low to medium amplitude. This seismic character typifies sub-basement reflectors of seismic profiles through the western margin of the forearc basin. An order-of-magnitude increase in resistivity occurs at the sediment-basement interface; within basement, varying resistivity values indicate the presence of alternating massive and altered/brecciated units. In general, low resistivity, velocity, density, aluminum, iron, and silicon values characterize altered sections (Fig. 11). At the Unit V/VI contact, permeability and porosity drop sharply and velocity increases. 


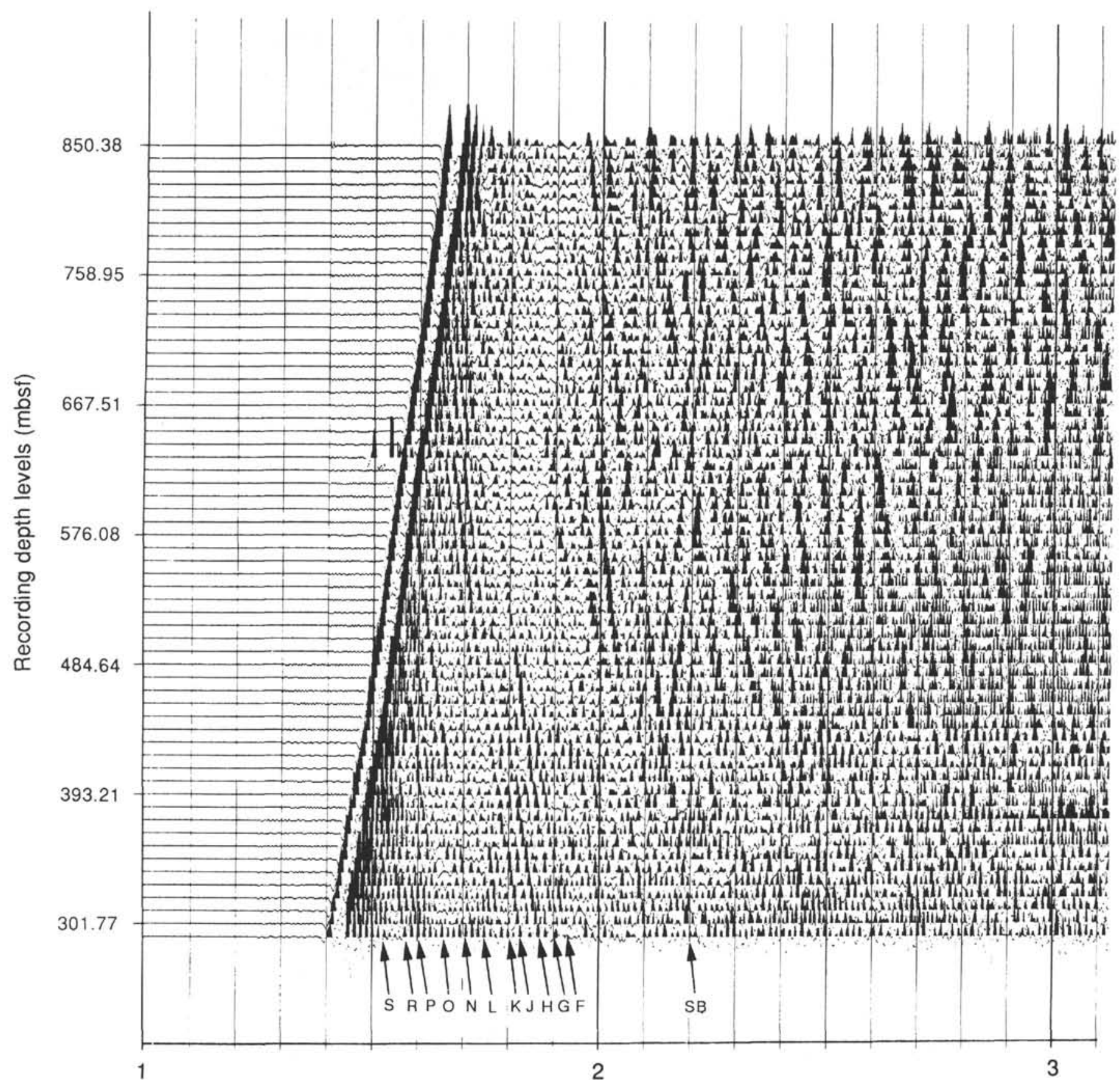

One-way traveltime (s)

Figure 6. Stacked, filtered, composite depth vs. one-way traveltime VSP seismic section (with automatic gain control applied) for Hole 792E; corrected only for blanking time.

\section{SITE 793}

Site 793 occurs on multichannel seismic Line 12 (Fred Moore 3505) at 0109:30 Z (Fig. 12). The site is located in the central Izu-Bonin forearc sedimentary basin, in an interchannel area on the southern side of the broad Sumisu Jima Valley; the active channels are located at $0053-0100 \mathrm{Z}$ and $0116-0121 \mathrm{Z}$ on Line 12. Correlations between the MCS reflection data, recovered core material, and logging data were done using velocities obtained from physical properties measurements, averaged over lithologic units, to convert depths into two-way traveltimes. Stacking velocities were substituted in the uncored depth range from 99.7 to $586.5 \mathrm{mbsf}$; physical properties and stacking velocities are in good agreement for the cored intervals at this site.

Seismic Unit 1 may be divided into two subunits. Subunit $1 \mathrm{~A}$ $(3.97-4.09 \mathrm{~s})$ is characterized by discontinuous, hummocky, highamplitude reflectors; it exhibits evidence of migrating, dunelike features, possibly current-deposited ridges. Subunit $1 \mathrm{~B}(4.09-4.75 \mathrm{~s})$ is characterized by parallel, continuous, low-to medium-amplitude reflectors. Subunit $1 \mathrm{~A}$ was cored and corresponds to lithologic Unit I. 


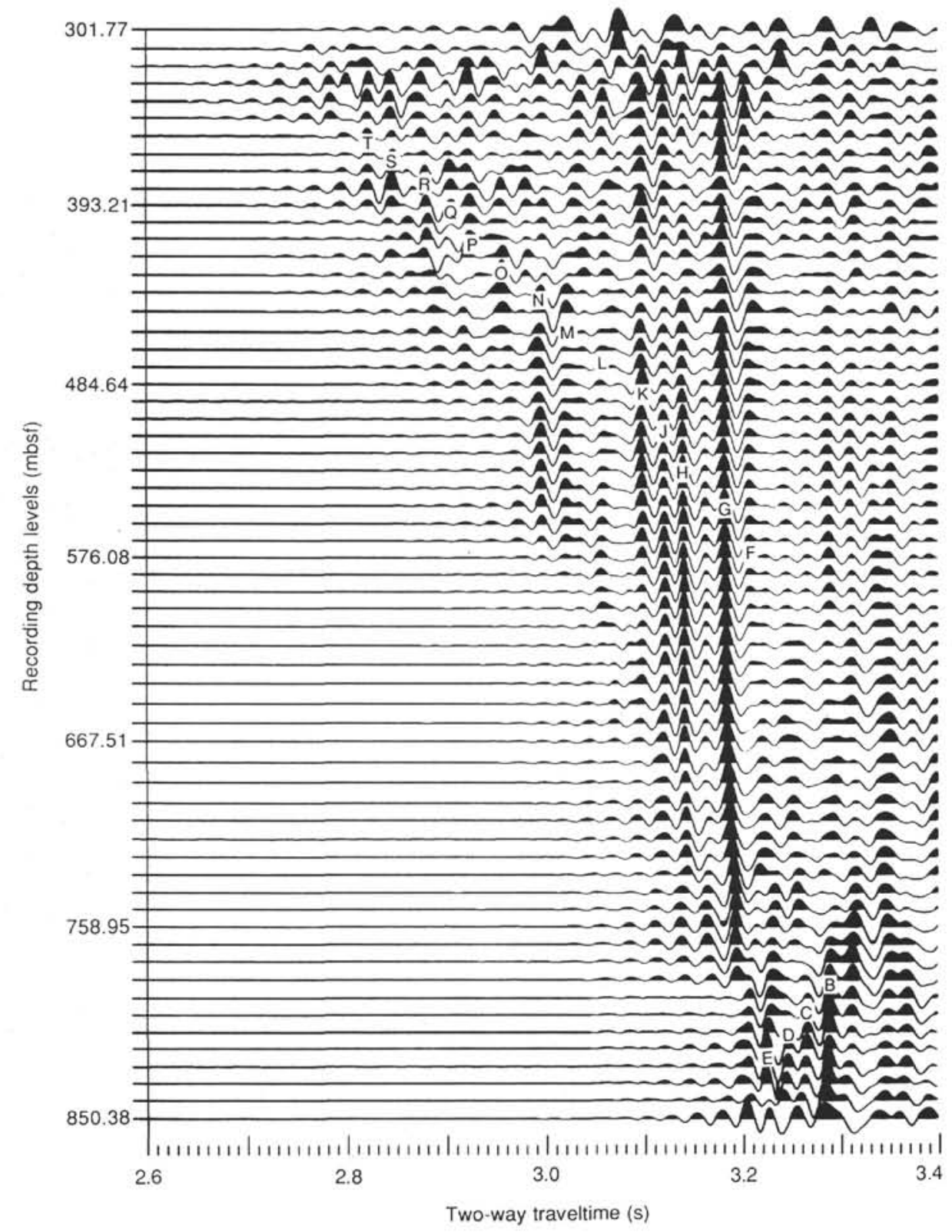

Figure 7. Two-way traveltime plot of deconvolved, upgoing wave trains, Hole 792E. The reflectors are identified by letter (for correlation with synthetic seismogram and MCS) and are related to corresponding lithologic units or depths, where such correlation is possible, in Table 1.

The MCS data reveals an older, probably Pliocene, erosional surface of similar dimensions beneath the modern submarine valley, the base of which can be seen at $4.46 \mathrm{~s}$ at $0053 \mathrm{Z}$ in Figure 13. A portion of the Quaternary sediments filling the paleo-canyon was recovered in Hole 793A (Unit I). The remainder of the canyon fill, its erosional contact with the underlying sediment, and the seismic section to 586.5 mbsf were not cored. At about 55 mbsf a sharp drop in magnetic susceptibility occurs. Unit I velocities range from 1.54 to $1.65 \mathrm{~km} / \mathrm{s}$. Coring resumed at $586.5 \mathrm{mbsf}$, within the lower portion of seismic Subunit 1B; a diabase sill was encountered, which constitutes lithologic Unit II. Unit II is a high-Mg tholeiitic diabase sill; low porosity and high density and velocity $(4.88 \mathrm{~km} / \mathrm{s})$ values characterize the unit, but it is too thin $(4.5 \mathrm{~m})$ to be resolved by the MCS data. The disturbed reflector at $4.64 \mathrm{~s}$ is the approximate location of the Unit II/III boundary in the seismic section (Fig. 13). The uppermost part of Unit III is a cap of burrowed fine-grained rock. A sharp increase in thorium between 655 and 665 mbsf (Fig. 14) together with a small decrease in resistivity, corresponding to the reflector at $4.70 \mathrm{~s}$, could indicate a minor unconformity. Although there is no statistically significant increase in velocity, carbonate content, as measured in the laboratory, is very high over this interval $(20 \%-43 \%)$. Unit III comprises lower to middle Miocene hemipelagic deposits. Based on a lack of thick-bedded, coarse-grained beds and the sheetlike geometry of the basin fill on MCS profiles, the depositional setting was a featureless basin plain, onto which hemipelagic sediments settled. The small grain sizes and the total volume of volcanic ejecta in this unit suggest limited activity at nearby volcanoes.

A hiatus at $725 \mathrm{~m}$ between the early Miocene and the late-early Miocene (about 1.9 m.y. in duration) probably corresponds to Reflector R1 at $4.75 \mathrm{~s} \mathrm{(Fig.} \mathrm{13).} \mathrm{Reflectors} \mathrm{of} \mathrm{Subunit} \mathrm{1A} \mathrm{lap} \mathrm{onto} \mathrm{those} \mathrm{of}$ Unit 2 along Reflector R1 throughout the basin. Seismic Unit 2 $(4.75-4.78 \mathrm{~s})$ includes the base of Unit III and all of Unit IV. The Unit 


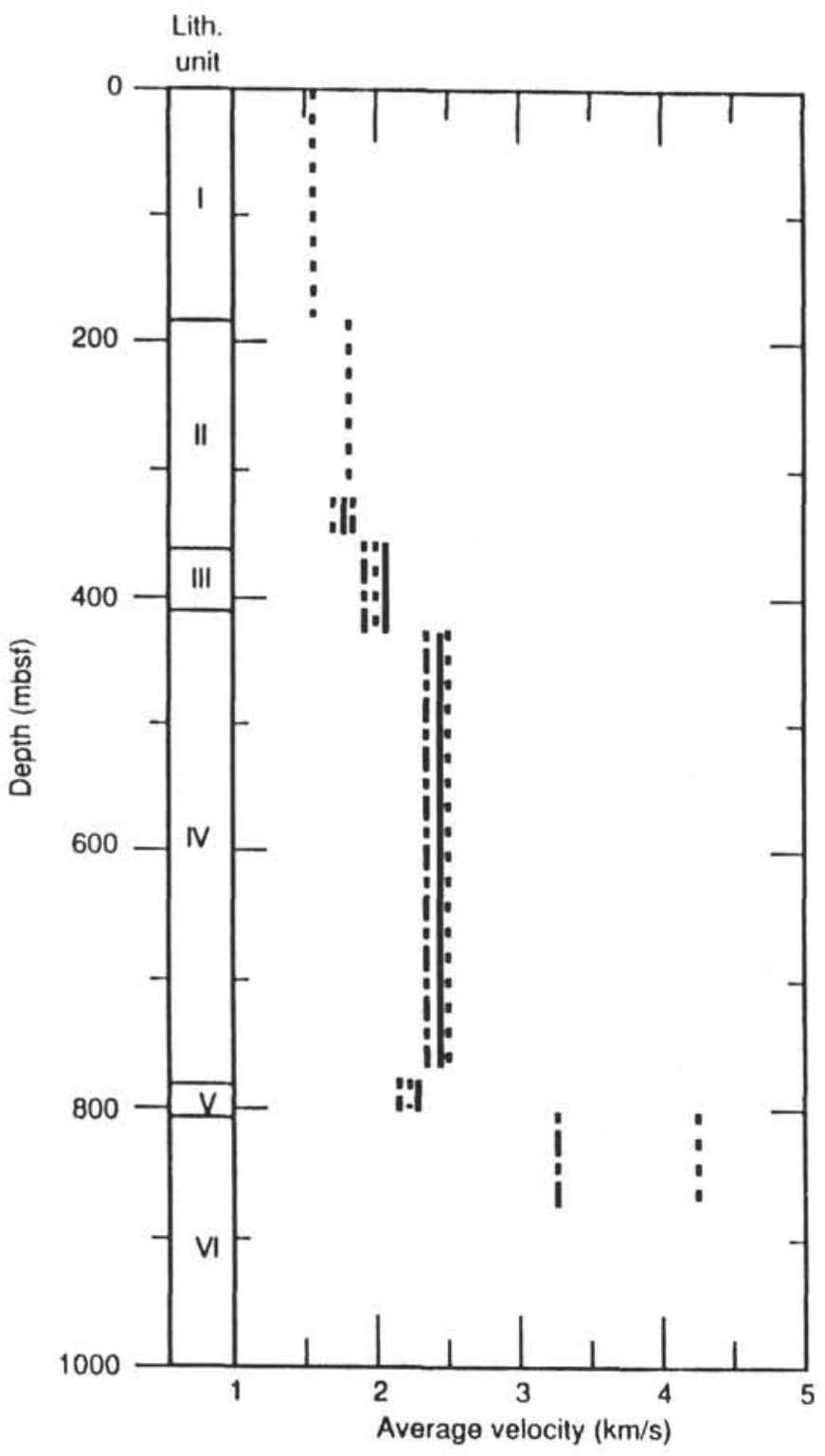

Figure 8. Comparison of physical properties (dashed line), VSP (solid line), and in situ velocity measurements. Lithologic units are shown on the left for reference.

III/IV boundary exhibits a change in lithology but little change in velocity; furthermore, the top of Unit IV is extensively burrowed and impermeable. Unit IV consists of pelagites with slow deposition rates and an almost complete absence of direct volcanogenic input. An unconformity marks the lower boundary of Unit IV, coincident with Reflector R2; this boundary also shows a $0.5-\mathrm{km} / \mathrm{s}$ increase in velocity, an increase in sedimentation rate from $7 \mathrm{~m} / \mathrm{m}$.y. in Unit IV to $80 \mathrm{~m} / \mathrm{m} . \mathrm{y}$. in Unit $\mathrm{V}$, a sharp increase in magnetic susceptibility, and a very sharp increase in $\mathrm{CaCO}_{3}$.

Parallel, continuous, or locally divergent, medium- to high-amplitude reflectors characterize Seismic Unit 3 (4.78-5.24 s). Unit 3 includes lithologic Units V and VI. Unit V consists of sedimentary gravity flows (debris flows and turbidity currents) that resulted from the erosion of arc volcanoes and nonexplosive volcanic activity. Grain size within the unit shows an overall fining-upward trend (Fig. 14); conglomerates are interspersed throughout the unit; hence, velocity values are highly variable. Some evidence for contemporaneous explosive and acidic volcanic activity exists; from 900 to $1020 \mathrm{mbsf}$ a series of conglomerate beds containing a large quantity of pumice in sandstone (low bulk density) constitute an
Table 1. Summary of VSP correlations, Site 792.

\begin{tabular}{|c|c|c|c|}
\hline $\begin{array}{l}\text { Reflector } \\
\text { label }\end{array}$ & $\begin{array}{l}\text { Two-way } \\
\text { traveltime (s) }\end{array}$ & $\begin{array}{l}\text { Depth } \\
\text { (mbsf) }\end{array}$ & $\begin{array}{l}\text { Corresponding MCS } \\
\text { reflector and/or lithologic feature }\end{array}$ \\
\hline $\mathbf{T}$ & 2.83 & $374.92-384.06$ & Sharp increase in $\mathrm{CaCO}_{3}$ content \\
\hline$\dot{s}$ & 2.85 & $384.06-393.21$ & \\
\hline $\mathbf{R}$ & 2.89 & $411.44-420.34$ & R2, Unit III/IV boundary ( $27 \mathrm{Ma}$ ) \\
\hline Q & 2.91 & Poorly defined & \\
\hline $\mathrm{p}$ & 2.94 & Poorly defined & \\
\hline o & 2.77 & $512.07-521.22$ & Subunit IVA/IVB boundary \\
\hline $\mathrm{N}$ & 3.01 & $548.65-557.79$ & Subunit IVB/IVC boundary \\
\hline$M$ & 3.03 & $566.94-603.51$ & \\
\hline $\mathrm{L}$ & 3.06 & $621.80-630.94$ & \\
\hline $\mathrm{L}$ & 3.10 & $667.51-676.66$ & Top of sandstones at about $670 \mathrm{mbsf}$ \\
\hline $\mathrm{j}$ & 3.13 & 694.95-704.09 & \\
\hline $\mathrm{H}$ & 3.15 & $722.37-731.52$ & $\begin{array}{l}\text { R3? upper/lower Oligocene unconformity? } \\
(\geq 29 \mathrm{Ma}<34 \mathrm{Ma})\end{array}$ \\
\hline G & 3.21 & $777.23-786.37$ & Basal conglomerates and top of altered zone \\
\hline $\mathrm{F}$ & 3.23 & $786.37-795.52$ & $\mathrm{R} 4,34-\mathrm{Ma}$ are volcanics \\
\hline
\end{tabular}

interval of weak, discontinuous reflectors. No evidence exists to indicate that the basal conglomerates were channel deposits; conglomerate units higher up in the section, interbedded with turbidites, represent high-volume debris flows from slope failure (uplift?). Conglomerates at $28 \pm 0.5 \mathrm{Ma}$ are contemporaneous with conglomerates at the base of the sedimentary section at Hole 792E. Uplift of the flanks of the rift, deepening of the basin, steepening of the bottom slopes, and increased seismic activity, all led to the coarse-grained, thickly bedded basal Unit V. Upward fining occurred above the conglomerates, probably a result of decreasing extension, a decline in source elevation, and the reduction of slopes by infilling. Volcanic clasts are andesite, dacite, basalt, and pumice. Very little difference exists between the two units in measured physical properties, seismic characteristics, or geochemical logging measurements; hence, no reflector defines this boundary. Unit VI consists of poorly sorted, altered volcanic breccia atop basement.

Seismic Unit 5 is acoustic basement, corresponding to lithologic Unit VII. The boundary between Seismic Units 3 and 5 (basement > $5.24 \mathrm{~s}$ ) is defined here by the contrast between the highly chaotic and discontinuous reflectors of Unit 5 that underlie the well-stratified Unit 3 sequences. The Unit VI/VII boundary is clearly revealed by the logging data: note the sharp peaks in $\mathrm{CaO}, \mathrm{FeO}, \mathrm{TiO}_{2}, \mathrm{Al}_{2} \mathrm{O}_{3}$, and $\mathrm{SiO}_{2}$ (Fig. 14) and to a certain degree in sonic velocity. Basement is not well defined by physical properties data because of a gradual transition through breccias. Unit VII (basement) consists of pillowed and massive andesitic and boninitic flows, deposited about $\geq 32 \mathrm{Ma}$, interbedded with breccias. Basement is clearly stratified. Pre-middle Oligocene sediment is absent in the forearc basin depocenter.

\section{CONCLUSIONS}

Sites 792 and 793, drilled within the Izu-Bonin forearc sedimentary basin during Leg 126, recovered an igneous basement (Seismic Unit 5) formed by early Oligocene arc volcanism. At Site 792, basement consists of andesitic and minor dacitic massive flows with intercalated hyaloclastites and breccias. Breccias and massive to pillowed flows of basaltic and high- $\mathrm{Mg}$ andesites with boninitic affinities constitute basement at Site 793. Sites 782 and 786, drilled during Leg 125, recovered middle Eocene, island-arc tholeiites and boninite on the outer-arc high. Therefore, basement rocks of the outer-arc high, frontal-arc high, and central forearc basin are all of island-arc origin. Downdropped and rotated blocks of Eocene forearc may form a sub-basement beneath the flows in the central forearc basin. Basement at Site 792 was defined using the VSP and logging data. Deep reflectors observed on the vertical seismic profile may originate in the Eocene sub-basement.

The onset of the crustal extension that formed the basin is hard to date accurately, but it probably did not begin before $34 \mathrm{Ma}$ and was finished by about $27 \mathrm{Ma}$. This early extensional event may have coincided with rifting in the Mariana backarc to the south and heralded the breakup of the Izu-Bonin Arc. The extension was accommodated on early, north-northwest-striking faults and on younger, more northerly striking faults, as defined by the MCS data. The oldest 


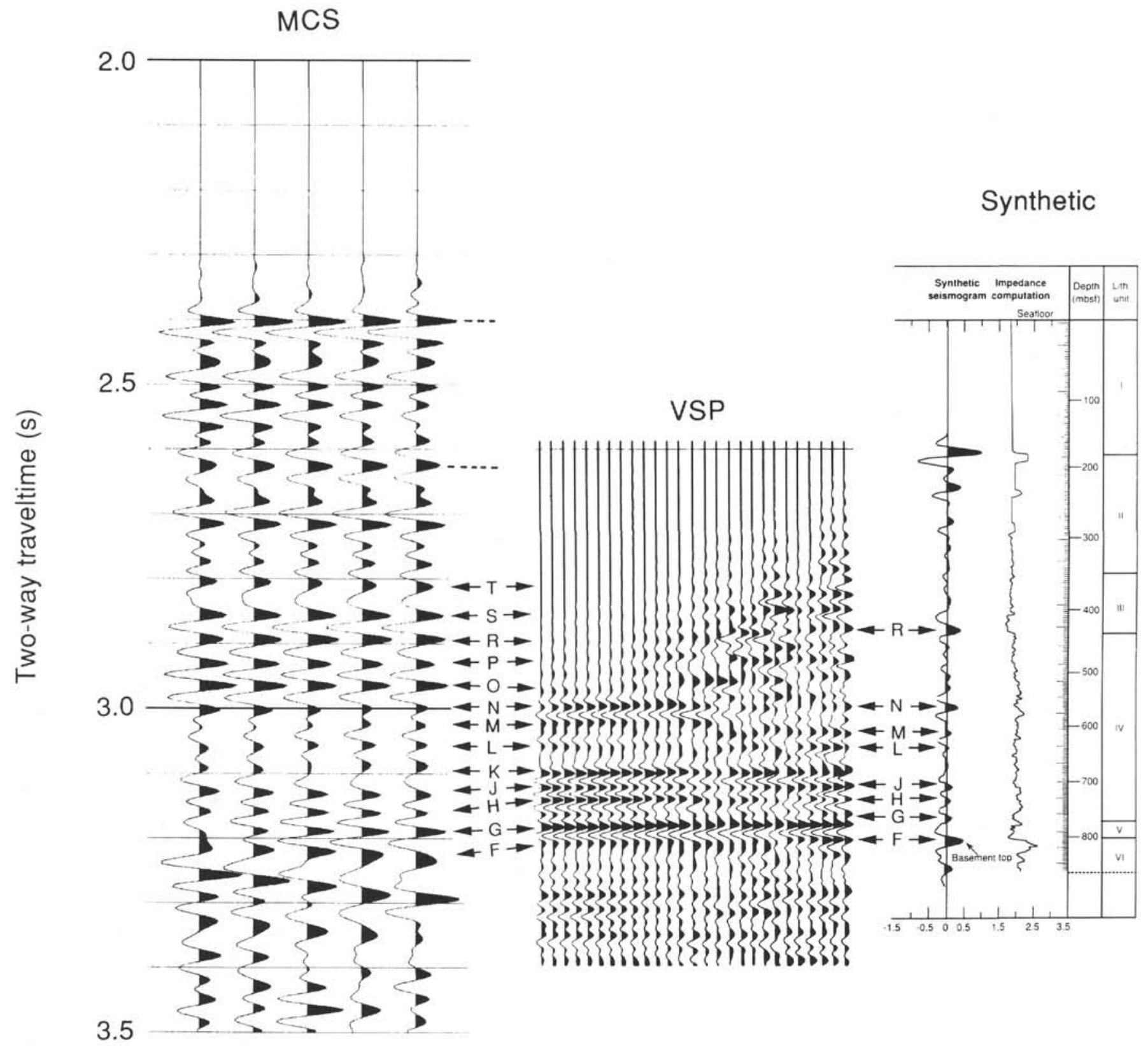

Figure 9. Correlation of MCS, VSP, and the synthetic seismogram computed from in situ velocity and density measurements at Site 792. The synthetic seismogram is computed from velocity and bulk density in situ measurements and convolved with a 30-Hz Ricker wavelet. The uppermost portion of the synthetic is computed from physical properties velocities.

well-dated sediment was recovered at Site 793; however, the sediment below the unconformity at Site 792 is probably older ( $>29 \mathrm{Ma}$ and $\leq 34 \mathrm{Ma})$. The MCS data show that normal faulting continued during the rapid deposition of the late Oligocene volcaniclastics, but at a decreased rate into the earliest Miocene, when most normal faulting ceased. Based on unit thicknesses and grain sizes, the sources of the volcaniclastics were arc volcanism to the west, as well as erosion of the outer-arc high to the east.

Individual sub-basins ceased to be separate depocenters in the upper Oligocene, when deposits from the arc completely filled the sub-basins, and Neogene deposits now cap and form the eastern edge of the broad sedimentary prism bordering the island arc. Thick (1.5-4 km) sequences of undeformed, coarse-grained volcaniclastic and hemipelagic strata fill the 90-140-km-wide forearc sedimentary basin. Normal faults near the frontal-arc high downfault the strata away from the arc; similarly, normal faults near the outer-arc high downfault the strata toward the central basin.

Miocene sedimentation consists of pelagic or hemipelagic nannofossil-rich sequences (Unit 2). Arc volcanism was minimal throughout early Miocene time; seafloor spreading occurred during this time in the Shikoku Basin to the west. Much of the Miocene section in the forearc sedimentary basin has been removed by canyon formation and erosion, as at Sites 787 and 792 . Volcanic activity resumed in middle to late Miocene time, and abundant volcanic ash layers indicate continuous explosive volcanism throughout the late Pliocene and Pleistocene (Seismic Unit 1).

Changes in the styles of sedimentation and deposition in the forearc basin, as documented by the correlation of core samples to MCS data, probably occur with time as the provenance changes from both arc and outer-arc high to arc alone, as the basin fills, as the 


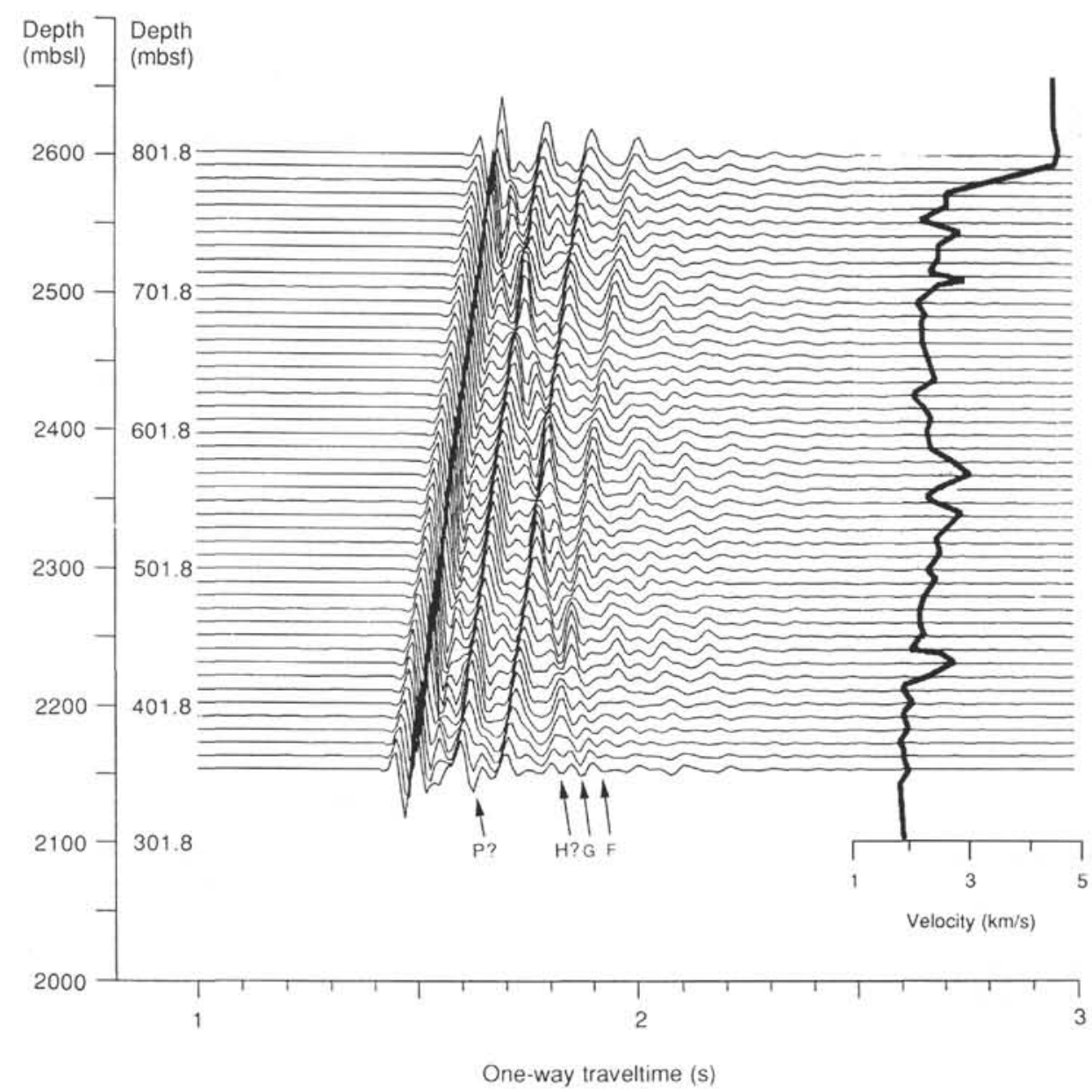

Figure 10. Synthetic VSP computed for physical properties velocity and density measurements for Hole $792 \mathrm{E}$. The velocity model is shown in the right portion of the figure. Question marks indicate the tentative identification of Reflectors P and H. Reflectors F and G originate at basement and at or within the altered zone above basement, respectively.

volume and eruptive style of arc volcanoes varies, and as submarine mass-wasting processes redistribute the sediments.

\section{REFERENCES}

Anderson, R. N., Dove, R. E., and Pratson, E., 1990. The calibration of geochemical well logs in basalt, granite and metamorphic rocks, and their use as a lithostratigraphic tool. $\ln$ Hurst, A., Lovell, M. A., and Morton, A. C. (Eds.), Geological Applications of Wireline Logs. Geol. Soc. London Spec. Pap., 48:177-194.

Balch, A. H., and Lee, M. Y., 1984. Vertical Seismic Profiling: Techniques, Applications, and Case Histories: Boston (Int. Human Resources Co.).

Gal'perin, E. I., 1974. Vertical Seismic Profiling. Soc. Explor. Geophys. Spec. Publ., No. 12

Hardage, B. A., 1983. Vertical Seismic Profiling. Part A: Principles: London (Geophysical Press).

Herzog, R., Colson, L., Seeman, B., O'Brien, M., Scott, H., McKeon, D., Wright, P., Grau, J., Ellis, D., Schweitzer, J., and Herron, M., 1987.
Geochemical logging and spectrometry tools. Soc. Pet. Eng., Spec. Pap., 16792:447-460.

Lovell, M. A., and Anderson, R. N., 1988. When downhole logging turns to geochemistry: continuous quantitative analysis of borehole rocks in situ. Geol. Today, 4:164-166.

Mallick, S., and Frazer, L. N., 1988. Rapid computation of multi-offset VSP synthetic seismograms in a stratified medium. Geophysics, 53:479-491.

Mutter, J. C., and Balch, A., 1988. Vertical Seismic Profiling (VSP) and the Ocean Drilling Program (ODP): Report of a Workshop. Joint Oceanogr. Inst./U.S. Science Advisory Comm.

Taylor, B., Fujioka, K., et al., 1990. Proc. ODP, Init. Repts., 126: College Station, TX (Ocean Drilling Program).

Date of initial receipt: 2 January 1991

Date of acceptance: 19 September 1991

Ms 126B-160 
Physical properties measurements

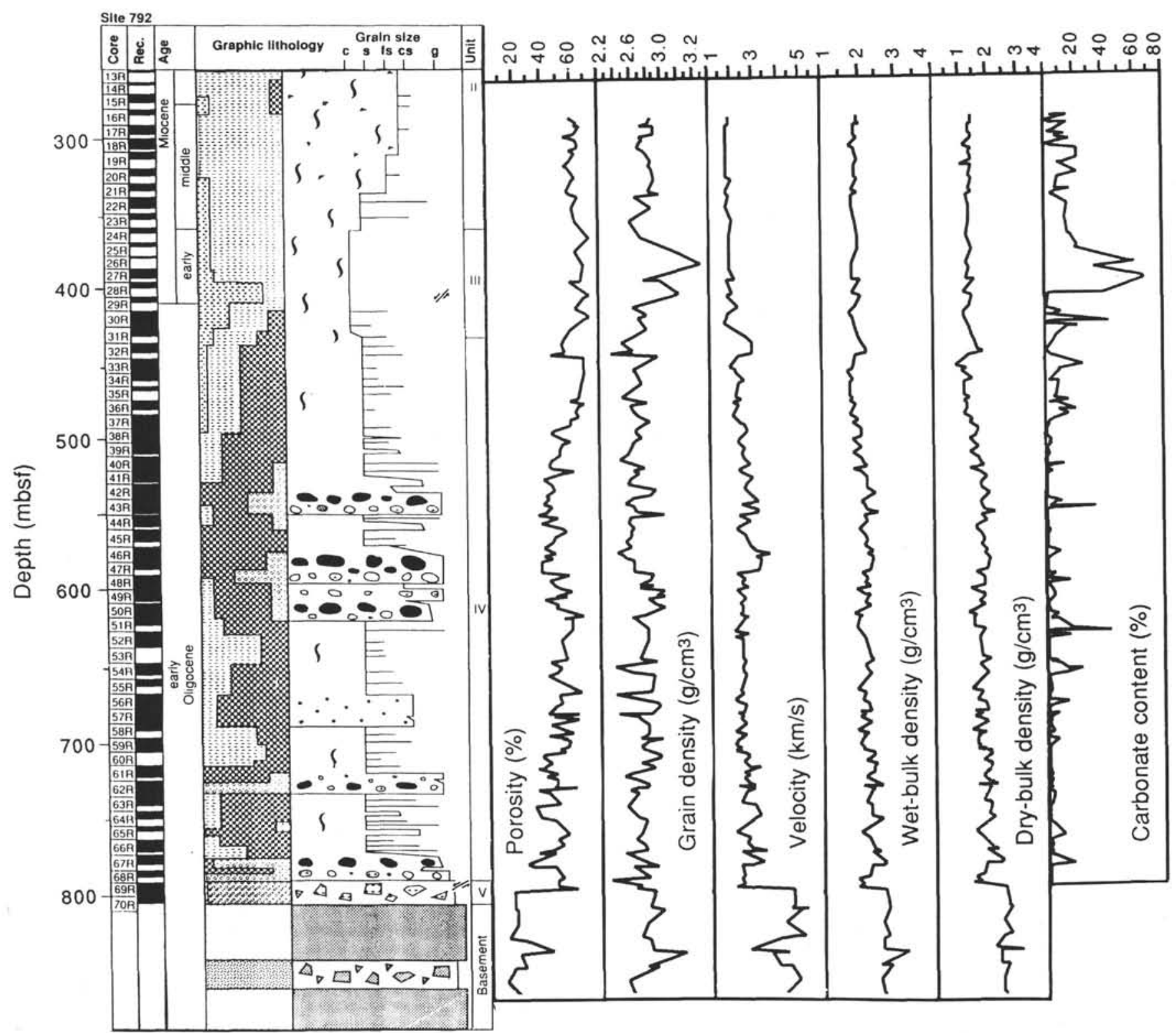

Figure 11. Site 792 comparison of lithologies, physical properties measurements, and estimates of oxide weight fractions from geochemical logs (solid squares are X-ray diffraction measurements). 
Downhole measurements

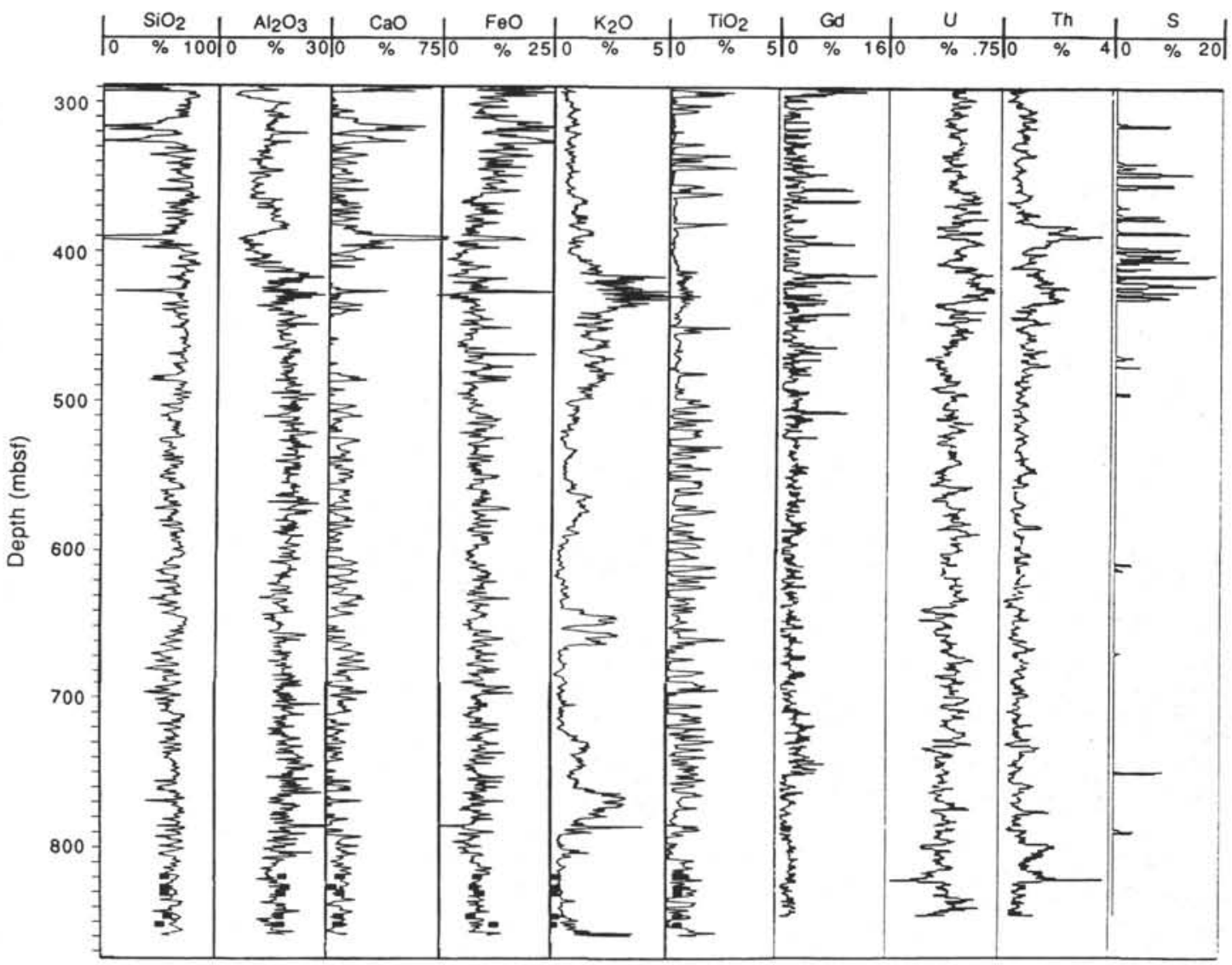

Figure 11 (continued). 


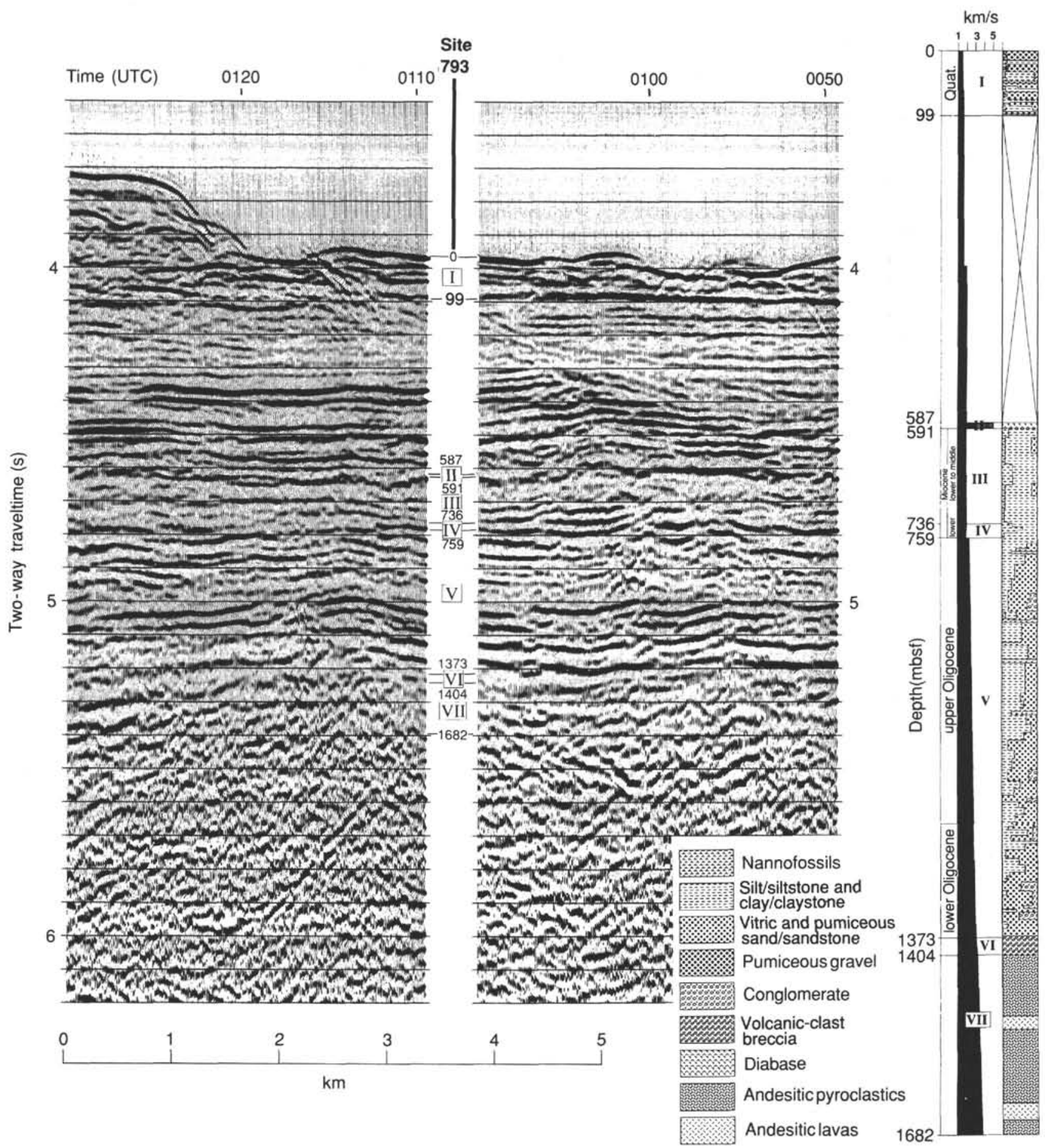

Figure 12. Correlation of Site 793 lithostratigraphy with site survey multichannel reflection data. Lithologic units are identified on the same section, unit boundaries are given in meters below seafloor (mbsl), and the lithologic column is presented at right. The location of the seismic line is shown in Figure 1. The seismic section has been stacked (48-fold), deconvolved, migrated and filtered $10-60 \mathrm{~Hz}$. Vertical exaggeration is about $4 \times$. 


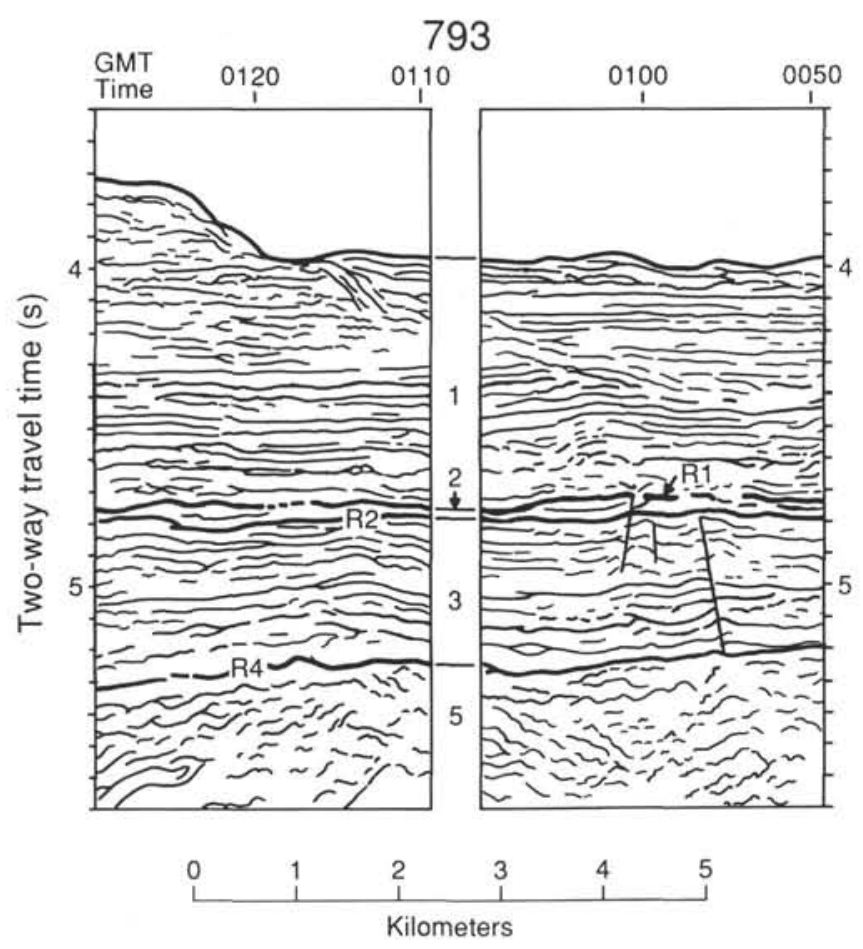

Figure 13. Interpretation of MCS Line 12 near Site 793 showing major Reflectors R1, R2, and R4 and Seismic Units 1, 2,3, and 5. See text for further explanation. 
Physical properties measurements

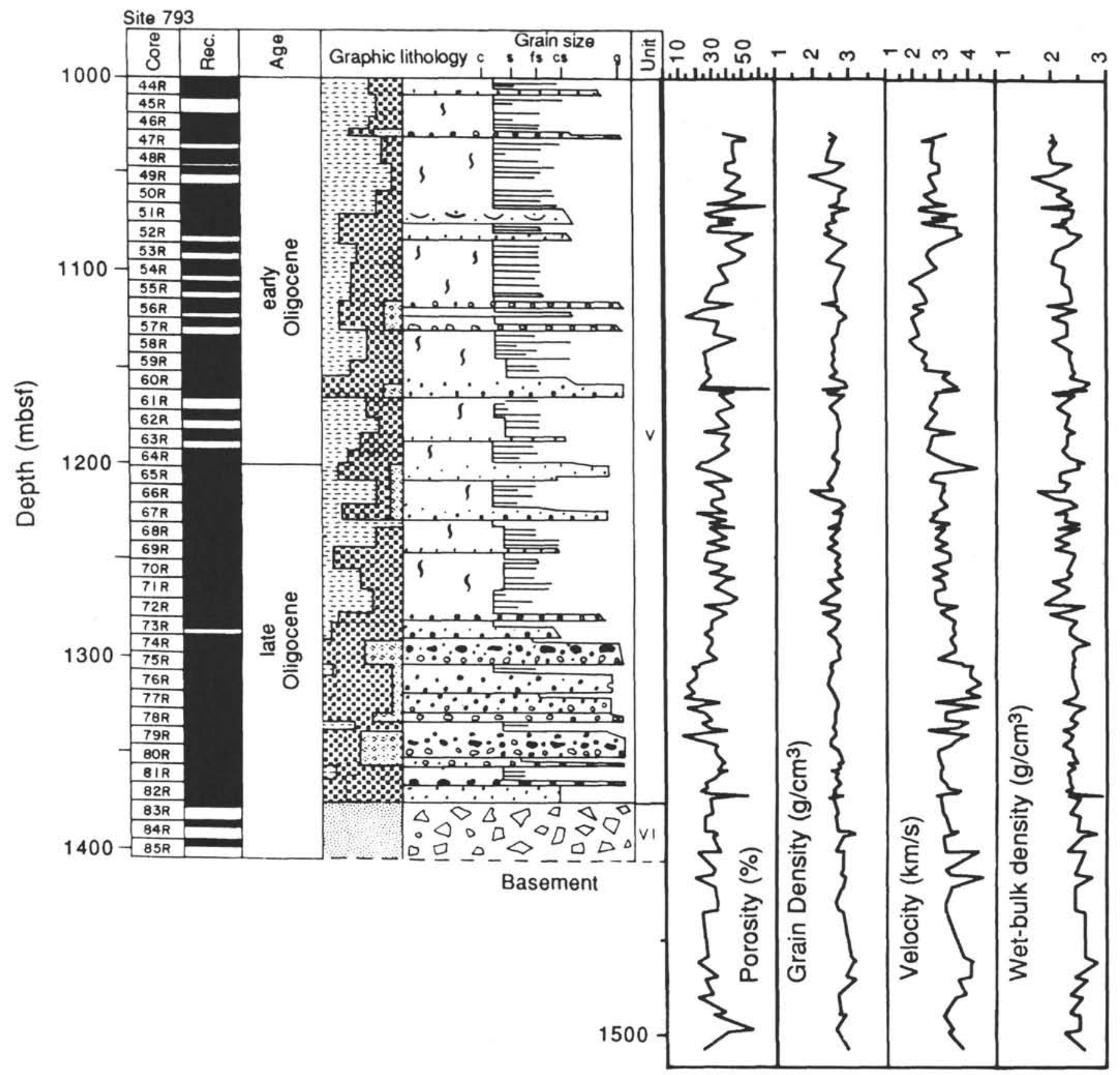

Figure 14. Site 793 comparison of lithologies, physical properties measurements, and estimates of oxide weight fractions from geochemical logs (solid squares are X-ray diffraction measurements). 
Downhole measurements

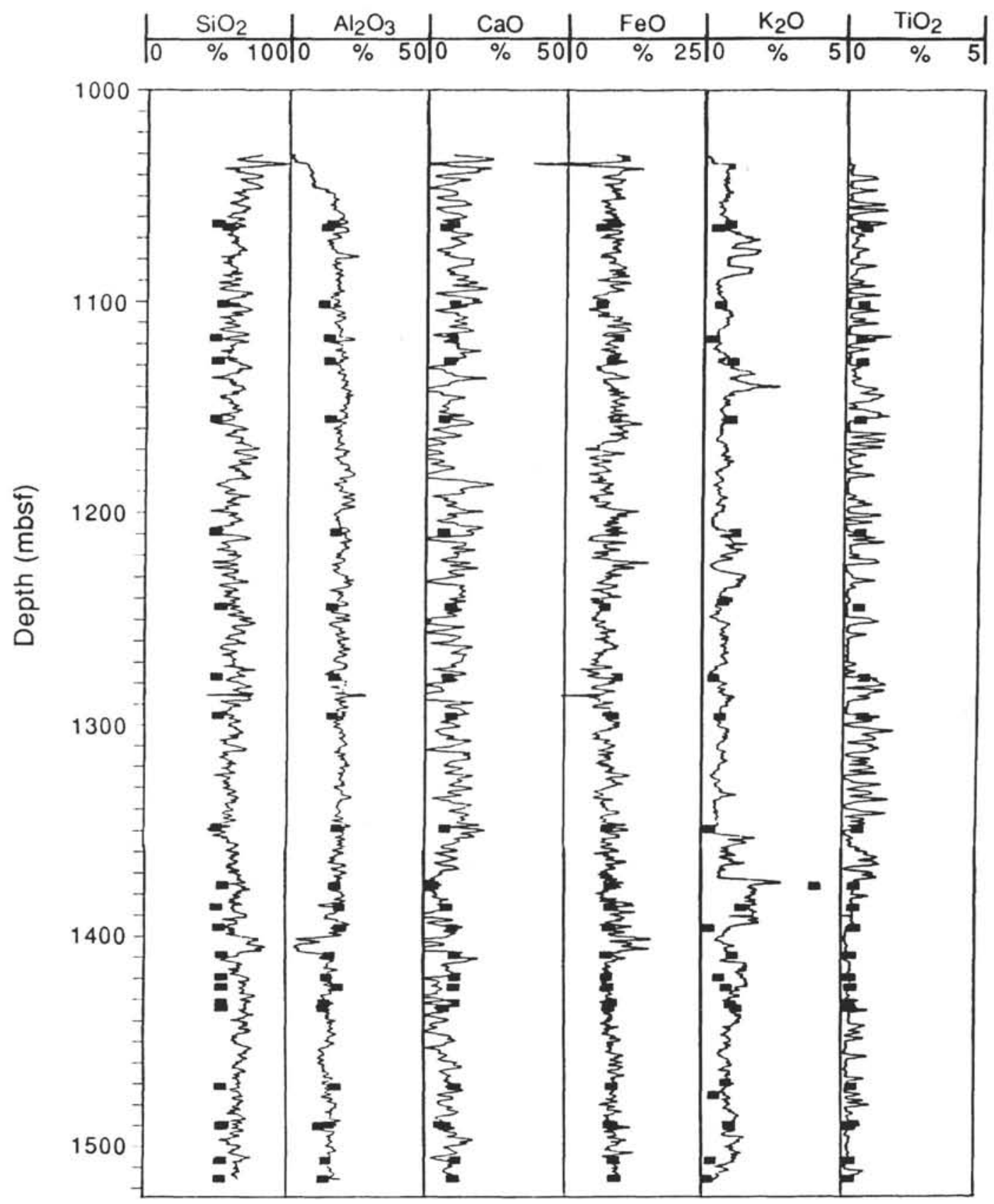

Figure 14 (continued). 